\title{
Perceived Justice in Service Recovery and Recovery Satisfaction: The Moderating Role of Corporate Image
}

\author{
Davoud Nikbin (Corresponding author) \\ PhD Student, School of Management, Universiti Sains Malaysia \\ Minden Campus, Penang 11800, Malaysia \\ E-mail: nikbin_david@yahoo.com
}

Ishak Ismail

School of Management, Universiti Sains Malaysia

Minden Campus, Penang 11800, Malaysia

Malliga Marimuthu

School of Management, Universiti Sains Malaysia

Minden Campus, Penang 11800, Malaysia

Mohammad Jalalkamali

School of Management, Universiti Sains Malaysia

Minden Campus, Penang 11800, Malaysia

\begin{abstract}
The purpose of this study is to assess the influence of perceived justice on recovery satisfaction and to examine the moderating role of corporate image in the relationship between perceived justice and recovery satisfaction. Data were gathered on perceived justice with service recovery, corporate image and recovery satisfaction by means of survey from Iran Air customers who experienced a service failure within last year. The results show that distributive and interactional justices have significant effects on recovery satisfaction. The effect of distributive justice on recovery satisfaction was stronger than interactional justice. Additionally, hierarchical regression analyses suggested that corporate image plays a moderating role between perceived justice and recovery satisfaction in the distributive and interactional justice dimensions. Managerial implications of these findings are briefly discussed.
\end{abstract}

Keywords: Service failure, Service recovery, Perceived justice, Corporate image, Recovery satisfaction

\section{Introduction}

It does not matter how excellent the service a company delivers, every company still often makes mistakes in meeting the expectations of today's customers, who tend to be more demanding and less loyal than ever before. Bitner (1993) argues that due to the unique nature of services it is impossible to ensure $100 \%$ error-free service. Even the most customer-oriented organization with the strongest quality program is unlikely to be able to eliminate all service failures (del Río-Lanza, 2009). Service failure causes customer dissatisfaction with the service provider, and due to that customers may exit silently, spread a negative word-of-mouth, voice their complaints to the operator, or continue to patronage the same service provider despite their dissatisfaction (Kim et al., 2009). Therefore, service recovery is a moment of truth for the company, which is critical for satisfying its customers as well as strengthening its relationships with them (Blodgett et al., 1997; Smith \& Bolton, 2002).

Service recovery refers to the actions an organization takes in order to respond to a service failure (Gronroos, 1988). Service recovery strategies are strategies practiced by an organization and its employees to return the customer to a state of satisfaction (Danaher \& Mattsson, 1994; Sparks \& McColl-Kennedy, 2001). The ultimate goal of service recovery is to pacify dissatisfied customers through appropriate actions in order to reduce potential damage to customer relationships caused by service failures (Ha \& Jang, 2009; Zemke, 1993).

In order to more fundamentally comprehend effective service recovery, researchers have utilized justice theory as the main framework for examining service recovery procedures (McColl- Kennedy \& Sparks, 2003). A justice 
theory framework has gained popularity in explaining how customers evaluate service providers' reactions to service failure/recovery. In this theory, perceived justice is a multi-dimensional concept comprising three dimensions: distributive, procedural, and interactional justice. Despite the recent advances concerning the effects of perceived justice on post-recovery satisfaction, there is still room to learn how a service provider's recovery efforts affect subsequent customers' recovery satisfaction. There is still a need for solid empirical research regarding the impact of organizational responses to a customer complaint (Davidow, 2000, 2003). Moreover, according to Maxham and Netemeyer, (2002), there is a paucity of empirical research regarding the effects of complainants' perceptions of justice on satisfaction and intent. Therefore, there is interest in continuing to explore the relative influence of the dimensions of perceived justice on recovery satisfaction (del Río-Lanza et al., 2009).

Besides, Chebat and Slusarczyk (2005) observe that the specific effects of the three justice dimensions on customer loyalty are quite different from each other. But work analyzing whether the justice dimensions also affect satisfaction with service recovery differently is absent for the literature. Maxham and Netemeyer (2002) analyzed the effects of perceived justice on satisfaction with service recovery, but they did not examine the relative effects of the justice dimensions. Moreover, del Río-Lanza et al., (2009) state that since not all the dimensions of justice have the same relative importance in explaining satisfaction, they suggest the need to analyze the dimensions of perceived justice separately rather than in an aggregate form.

McCollough (1992) found that the impact of recovery on customer satisfaction was nonlinear, in other words, high recovery might not lead to high satisfaction while low recovery might not lead to low satisfaction. del Río-Lanza et al., (2009) recommends to consider moderating factors in the relationships between perceived justice and satisfaction. Among these variables, they recommended studying customers' image or evaluation of the firm's brand, and global satisfaction with the firm and their attributions of the causes of the problem. However, despite the importance of brand image, little effort has been made to investigate the role of brand image in relation to perceived justice regarding service recovery efforts and recovery satisfaction.

In this regard, the purpose of this study is to bridge these gaps in the literature by examining dimensions of perceived justice on recovery satisfaction and to analyze whether brand image moderates the relationship between perceived justice with service recovery and recovery satisfaction. The current study was conducted in the Iran Air.

\section{Literature Review and Hypotheses Development}

\subsection{Perceived justice with service recovery}

Customers and service providers cannot prevent the incidents that occur during exchange processes. Therefore, they expect fair behavior from each other and they do their evaluation based on perceived justice. Adams (1963) justice theory states that in every exchange that takes place, people weigh the inputs against the outcomes and compare them with those of others in similar situations. In the event that there is an equal balance between them, the exchange is considered as 'fair', but if the outcomes do not meet with the person's expectations, then this results in inequity. Past research on service failure and recovery has presented considerable evidence of the suitability of the concept of justice as a basis for understanding the process of service recovery and its outcomes (Blodgett et al., 1997; Goodwin \& Ross, 1992; Smith et al., 1999; Tax et al., 1998).

\subsubsection{Distributive justice}

Distributive justice refers to the assignment of tangible resources by the firm to rectify and compensate for a service failure (del Río-Lanza, 2009). In a service failure/recovery context, it refers to the perceived fairness of the service failure/recovery outcome (Holloway et al., 2009). When an individual perceives that benefits have not been allocated equitably, he/she experiences distress (Walster et al., 1973), which in turn motivates him/her to restore the distributive justice. Studies have provided empirical evidence that perceived fairness of tangible outcomes have a positive effect on recovery evaluation (Boshoff, 1997; Goodwin \& Ross, 1992; Hoffman et al., 1995; Smith et al., 1999). Previous literature in service recovery have measured distributive justice by the "justice," "fairness," "need," "value" and "reward" of outcomes (Chebat \& Slusarczyk, 2005; Smith et al., 1999; Wirtz \& Mattila, 2004).

\subsubsection{Procedural justice}

Procedural justice refers to the methods the firm uses to deal with the problems arising during service delivery in aspects such as accessibility, timing/speed, process control, delay and flexibility to adapt to the consumer's recovery needs (del Río-Lanza, 2009). Procedural justice also includes policies, procedures, and tools that companies use to support communication with customers and specifically, the time taken to process complaints 
and to arrive at a decision (Davidow, 2003). In service recovery context, procedural justice means the customer's perception of justice for the several stages of procedures and processes needed to recover the failed service (Mattila, 2001). Procedural justice focuses on the way that the outcome is reached. Based on previous literature, there are six sub-dimensions for procedural justice, namely, flexibility, accessibility, process control, decision control, response speed and acceptance of responsibility (Blodgett et al., 1997; Tax et al., 1998; Thibaut \& Walker, 1975; del Río-Lanza et al., 2009).

\subsubsection{Interactional justice}

Interactional justice focuses on interpersonal interactions during the process of service delivery. It means the evaluation of the degree to which the customers have experienced justice in human interactions from the employees of service organization during the recovery process (Sparks \& McColl-Kennedy, 2001). In service recovery context, interactional justice means the evaluation of the degree to which the customers have experienced justice in human interactions from the employees of service firms during the recovery process (Sparks \& McColl-Kennedy, 2001). Previous literature states that there are six sub-dimensions for Interactional justice. These sub-dimensions are: courtesy, honesty, offering explanations, empathy, endeavor, and offering apologies (Clemmer, 1988; Tax et al., 1998, McColl-Kennedy \& Sparks 2003; del Río-Lanza et al., 2009).

\subsection{Corporate Image}

According to Grönroos (1988) and Keller (1993), corporate image is a perception of an organization held in consumer memory and works as a filter which influences the perception of the operation of the company. It is seen as the representation of a brand in the consumer's mind that is linked to an offering (Dobni \& Zinkhan, 1990), or a set of perceptions about a brand the consumer forms as reflected by brand associations (Keller, 1993). According to (Nguyen \& Leblanc, 2001) corporate image is related to the various physical and behavioral attributes of the firm, such as business name, architecture, variety of products/services, tradition, ideology, and to the impression of quality communicated by each person interacting with the firm's clients.

The corporate brand is a valuable intangible asset, that is difficult to imitate, and which may help to achieve sustained superior financial performance (Roberts \& Dowling, 2002). Good brand image not only indicates that the brand has a positive image but also shows a higher level of brand image strength than other brands (Kim \& Kim, 2005).

\subsection{Perceived justice and recovery satisfaction}

Customers' satisfaction and future loyalty is dependent on customers' feelings on whether they have been treated fairly or not. Customers expect a service recovery to be fair in order to recover their satisfaction and loyalty. The effects of perceived justice with service recovery and customer satisfaction has stated by a number of researchers. Zemke (1993) states the objective of service recovery efforts is to move a customer from a state of dissatisfaction to a state of satisfaction. Wirtz and Mattila (2004) indicate that recovery outcomes (e.g. compensation), procedures (e.g. speed of recovery) and interactional treatment (e.g. apology) have a joint effect on post-recovery satisfaction.

The effect of perceived justice dimensions on recovery satisfaction also has been mentioned in past literature. Many authors have found that all three forms of justice including distributive justice, procedural justice, interactional justice have a positive effect on overall service recovery satisfaction (Patterson et al., 2006; dos Santos \& Fernandes, 2008; Kim et al., 2009; Karande et al., 2007; Karatepe, 2006; Ok et al., 2005; Smith et al., 1999; Tax et al., 1998; Clemmer \& Schneider, 1996; Kau \& Loh, 2006). The effects of dimensions of justice on customers' recovery satisfaction have been studied in different service industries as well, including, hotel customers, (Karatepe 2006), mobile phone buyers (Kau \& Loh 2006), Undergraduate students, hotel customers (Smith et al., 1999) and Airline passengers (McCollough et al., 2000). Thus, based on the above discussion, this study proposed the following hypotheses:

\section{H1. There is a positive relationship between perceived justice and recovery satisfaction.}

Hla. There is a positive relationship between distributive justice and recovery satisfaction.

$H 1 b$. There is a positive relationship between procedural justice and recovery satisfaction.

H1c. There is a positive relationship between interactional justice and recovery satisfaction.

\subsection{Perceived justice, recovery satisfaction and brand image}

As it was mentioned in the introduction section, past studies have examined the effect of perceived justice on recovery satisfaction (Karatepe, 2006; Kau \& Loh 2006; Smith et al., 1999; McCollough et al., 2000). However, the degrees of the relationship between perceived justice and recovery satisfaction might not be the same across 
corporate image levels. Kim \& Kim (2005) state that good brand image not only indicates that the brand has a positive image but also shows a higher level of brand image strength than other brands. Besides, based on Nguyen \& Leblanc (2001), high level of corporate image is related to a better perception of the quality, business name and ideology of the company. Therefore, a good corporate image is critical for companies.

Past studies posit that corporate image impacts customers' satisfaction (Andreassen \& Lindestad, 1998). Consumers who develop a positive mental schema of a brand will tend toward high customer satisfaction through a halo effect where all things associated with the brand are similarly valenced (Lai et al., 2009). In this respect, even though service failures occur from time to time, when customers have a positive mental schema of a brand, they will think that the company will benefit them in future. Therefore, the effect of perceived justice due to recovery efforts might have a stronger impact on the recovery satisfaction of customers who have a positive corporate image. Despite the potential importance of these findings, to our best knowledge, no previous studies have investigated the moderating role of brand image in relation to perceived justice in service recovery. Thus, this study proposed the following hypotheses:

H2. The effect of perceived justice on recovery satisfaction is higher when customers have a positive image of the company.

H2a. The effect of distributive justice on recovery satisfaction is higher when customers have a positive image of the company.

H2b. The effect of procedural justice on recovery satisfaction is higher when customers have a positive image of the company.

H2c. The effect of interactional justice on recovery satisfaction is higher when customers have a positive image of the company.

\subsection{Conceptual framework of the study}

In line with literature review and the purpose of study described in the beginning of the paper, the conceptual framework of this study was configured as illustrated in figure 1. Distributive, procedural and interactional justices will affect recovery satisfaction (H1a, H1b, H1c). Besides, corporate image moderates the relationship between distributive, procedural, and interactional justices and recovery satisfaction (H2a, H2b, H2c).

\section{Method}

\subsection{Sampling frame and data collection}

Data were collected from Iran Air customers. The respondents were approached by interviewers at Emam Khomeini International Airport in January 2010 while they were waiting for their flight. The main advantage of this procedure was the possibility of approaching airline customers without having to obtain customer records in advance. A screening question was asked to see if respondents encountered any service failure with Iran Air during the past one year. A self-administered questionnaire was distributed to these customers. The questionnaire was adapted from original English questionnaire items and then translated into Persian. Two linguists who were educated in the U.S. were involved in the translation process. A pilot test was performed by distributing the questionnaire to 35 Iran Air customers to refine the instrument by clarifying any ambiguous expressions or misrepresentation of the original meanings. Out of 300 surveys, the response rate was $39.33 \%$, representing a total of 118 returned questionnaires. Out of the 118 collected, 11 questionnaires were either incomplete or the answers were found to be unreliable, leaving a remaining 107 questionnaires that were retained for further data analysis.

\subsection{Measures}

Multiple item scales were used to measure each construct in this study. If possible, validated scales from previous literature were employed after a slight modification. In this study, the items in all scales were measured on a seven-point Likert-type scale ranging from "strongly disagree" (1) to "strongly agree" (7) except for corporate image in which three items were on seven-point scale of "Very Low" and "Very High" and the fourth item with "Much Worse" and "Much Better". A total of 25 items were used to capture the five constructs.

For this study, distributive justice was measured by a four-item scale adopted from Blodgett et al., (1997) and Smith et al., (1999). The procedural justice was measured by a four-item scale adapted from Blodgett et al., (1997) and Karatepe (2006). To measure the interactional justice construct, we used a five-item scale adapted from Karatepe (2006), Smith et al., (1999), and Tax et al., (1998). The recovery satisfaction scale was measured by a four-item scale adapted from Brown et al. (1996), as well as from Maxham \& Netemeyer (2002). The four-item scale for corporate image was adapted from (Zeithaml, 1988; Selnes, 1993). 


\section{Results}

\subsection{Respondents' demographic profile}

The demographic profile of respondents is presented in Table 1 . The sample consisted of $65.4 \%$ male and $35.6 \%$ female respondents. The findings also indicate that most of the respondents are aged between 31 to 40 years old. Almost $66.4 \%$ of the respondents were married, $32.7 \%$ single and $0.9 \%$ divorced. Over $25.2 \%$ of the respondents hold bachelor degree, $56.1 \%$ master, $8.4 \%$ certificate/diploma, $9.3 \mathrm{PhD} /$ doctorate and only $0.9 \%$ hold high school.

\subsection{Goodness of Measures}

Factor analysis was used to understand the underlying factor of variables in the proposed framework (Hair et al., 1998). A Varimax rotation method was applied to variables. The selected factors were based on eigenvalues equal to or greater than 1.00. In this research, the chosen cut off point for significance loading is minimum 0.50. Then, the factors and selected items were grouped and renamed accordingly.

Factor analysis was performed on thirteen items in the perceived justice with service recovery. The result is shown in Table 2. The KMO was 0.642 and Bartlett's test of sphericity was significant at the 0.00 level. The anti-image correlation matrix ranged from 0.574 to $0.687(<0.5)$, so, there were sufficient correlations among the items. Three factors were extracted with $72.47 \%$ of the variance. Factor one is labeled as interactional justice justice, factor two was labeled as distributive justice and the third factor was renamed as procedural justice.

\subsection{Reliability Analysis}

Reliability analysis is established by testing whether the items grouped under a factor are internally consistent and stable. Cronbach's alpha $(\alpha)$ was used to analyze the reliability of the instruments. Reliability over 0.80 is good; reliability in the range of 0.70 is acceptable; and reliability less than 0.60 is considered poor (Sekaran, 2003). The results of this analysis are shown in Table 4. Distributive justice, procedural justice, interactional justice, corporate image and recovery satisfaction are accepted based on Cronbach $\alpha$ above 0.70 .

\subsection{Hypotheses Testing}

Hierarchical regression analyses were conducted to test Hypotheses 1 (1a, 1b, 1c) and $2(2 a, 2 b, 2 c)$, the relationship between perceived justice dimensions and recovery satisfaction and the moderating role of corporate image in the relationship between perceived justice and recovery satisfaction. The first step of the hierarchical regression analyses indicated that two justice dimensions of distributive justice and interactional justice are positively related to recovery satisfaction, supporting Hypotheses 1a and 1c. However, the effect of procedural justice on recovery satisfaction was not supported. Thus Hypothesis $1 \mathrm{~b}$ is not accepted. This step also showed that the effect of distributive justice on recovery satisfaction was stronger than interactional justice. The second step of the analyses examined the direct effect of corporate image on recovery satisfaction. However, an explanation of the results is not provided here because it was not one of the study objectives and, thus, it was not hypothesized.

Step 3 revealed the moderating effect and interaction terms between perceived justice and corporate image. In the distributive and interactional justice dimensions, interaction terms were significant, supporting Hypotheses $2 \mathrm{a}$ and $2 \mathrm{c}$. Meanwhile, in the procedural justice dimension, interaction term was not significant, meaning that corporate image did not play a moderating role between perceived justice and recovery satisfaction, rejecting Hypothesis $2 \mathrm{~b}$. The details of the hierarchical regression are presented in table 4 .

\section{Discussion}

The empirical results testing the relationships between perceived justice with service recovery, and recovery satisfaction demonstrated that two dimensions of justice namely distributive and interactional justice are positively related to recovery satisfaction. The impact of distributive justice on recovery satisfaction appears to be stronger than that of interactional justice, which is consistent with the previous findings of Smith et al. (1999) and Maxham and Netemeyer (2002). The significant role of distributive justice in affecting customer satisfaction would be supported by fair distributive treatment such as refunds, discounts, and etc that are important in returning back satisfaction from Iran Air customers. Therefore, Iran Air management should implement an effective way of distributive justice. Iran Air management can do this task by implementing fair distributive treatment such as discounts, refunds, and etc which are important in returning back the customers' satisfaction. Interactional justice was another important predictor of recovery satisfaction. Thus, Iran Air should also implement an effective way of interactional justice. This task can be done by offering apologies, appearing courteous and respectful and showing empathy and attentiveness. 
In the distributive and interactional justice dimensions, interaction terms were significant, showing that corporate image plays a moderating role in the relationship between distributive and interactional justice and recovery satisfaction. However, in the procedural justice dimension, interaction term was not significant, meaning that corporate image did not play a moderating role between perceived justice and recovery satisfaction, indicating that procedural justice does not play a moderating role between procedural justice and recovery satisfaction. In other words, positive corporate image will not affect the effects of procedural justice on recovery satisfaction, even when they are responded quickly, in a timely manner and the procedure of complaint handling is not complicated.

\section{Implications}

Several important managerial implications emerge from this study. First, Iran Air should train employees to understand what aspects of perceived justice, the fair distributive treatment, interpersonal communication is important to the customers. If Iran Air can improve these aspects of service recovery, the customers will be satisfied with service recovery that benefits the company in future.

Second, in order to enhance distributive justice which had a stronger relationship with recovery satisfaction; Iran Air should develop specific monetary compensation guidelines while training both full-time and part-time employees to quickly and properly react to various service failure situations. Depending on different levels of complaints and different situations of customers, Iran Air needs to train front desk staff to offer proper arrays of compensations with similar values and let their customers select the best compensation (Kim et al., 2009). In addition to distributive treatment training, Iran Air should also implement a training program, which clearly illustrates the reactions improving the interactional justice practice through teaching how to properly treat angry and frustrated customers, showing empathy and apology.

Third, the study also demonstrated that corporate image plays a moderating role in the relationship between perceived justice and recovery satisfaction in distributive and interactional justice situations. However, the moderating role of corporate image was not found in the procedural justice dimension. Therefore, Iran Air needs to make continuous efforts to create and hold a positive image and perception in the mind of customers, even in service failure/recovery situations.

\section{Limitations and Future Research}

This study like all other studies suffers from various limitations, that restrict the generalization of the findings and opens directions for future research. First, since this study only focused on one service sector (airline industry) and in a specific country, the findings cannot be generalized to other service sectors and different geographical areas. Therefore, future research can replicate this study in other service sectors and different countries.

A second limitation refers to the sample of this study. This study used a convenience sampling method consisting of 107 responses. Future research can overcome this limitation by taking a larger, randomly-selected, sample which may provide a more comprehensive result.

In addition, future research may consider some other moderating variables in the relationship between perceived justice with service recovery and recovery satisfaction. Among these variables, the authors recommend customers personality.

\section{Conclusion}

Prior service recovery research has developed an understanding of the role of perceived justice on recovery satisfaction. However, this study additionally examined the role of corporate image in service recovery situations. The purpose of the study was to examine dimensions of perceived justice on recovery satisfaction and to analyze whether brand image moderates the relationship between perceived justice with service recovery and recovery satisfaction. Based on the responses from the 107 respondents, the results indicate that distributive justice and interactional justice have a positive relationship with recovery satisfaction. The results also confirmed the moderating role of corporate image in the relationship between perceived justice and recovery satisfaction.

\section{References}

Adams, J. S. (1963). Toward an understanding of inequity. Journal of Abnormal and Social Psychology, 67, $422-36$.

Andreassen, T. W., \& Lindestad, B. (1998). Customer loyalty and complex services: the impact of corporate image on quality, customer satisfaction and loyalty for customers with varying degrees of service expertise. International Journal of Service Industry Management, 9 (1), 7-23. 
Bitner, M. J. (1993). Managing the evidence of service. In Scheuing, E.E., Christopher, W.F. (Eds),The Service Quality Handbook, American Management Association (AMACOM), New York, NY, 358-70.

Blodgett, J. G., Hill, D. J., \& Tax, S. S. (1997). The effects of distributive, procedural, and interactional justice on post-complaint behavior. Journal of Retailing, 73(2), 185-210.

Chebat, J. C., \& Slusarczyk, W. (2005). How emotions mediate the effects of perceived justice on loyalty in service recovery situations: an empirical study. Journal of Business Research, 58(5), 664-73.

Clemmer, E. C., \& Schneider, B. (1996). Fair service. In T. A. Swartz, D. E. Bowen, \& S. W. Brown (Eds.), Advances in services marketing and management (pp. 109-126). Greenwich, CT: JAI Press.

Clemmer, E. C. (1988). The role of fairness in customer satisfaction with services. Doctoral dissertation, Psychology Department, University of Maryland, College Park, MD.

Danaher, P. J., \& Mattsson, J. (1994). Customer satisfaction during the service delivery process. European Journal of Marketing, 28, 5-16.

Davidow, M. (2000). The bottom line impact of organizational responses to customer complaints. Journal of Hospitality \& Tourism Research, 24(4), 473-490.

Davidow, M. (2003). Organizational responses to customer complaints: what works and what doesn't?. Journal of Service Research, 5(3), 225-50.

del Rio-Lanza, A. B., Vazquez-Casielles, R., \& Diaz-Martin A.M. (2009). Satisfaction with service recovery: Perceived justice and emotional responses. Journal of Business Research, 62(8), 775-781.

Dobni, D., \& Zinkhan, G. M. (1990). In search of brand image: A foundation analysis, Goldberg, M E, Gorn, G, and Pollay, RW. Advances for Consumer Research, 17, 110-118.

dos Santos, C. P., \& Fernandes, D. V. H. (2008). Antecedents and Consequences of Consumer Trust in the Context of Service Recovery. Brazilian Administrative Review, 5(3), 225-244.

Goodwin, C. \& Ross, I. (1992). Consumer responses to service failures: influence of procedural and interactional fairness perceptions. Journal of Business Research, 25, 149-63.

Gronroos, C. (1988). Service Quality: The Six Criteria of Good Perceived Service Quality. Review of Business [St John's University], 9(3), 10-13.

Hair, J. F., Anderson, R. E., Tatham, R. L., \& Black, W. C. (1998). Multivariate data analysis. New Jersey: Practice Hall. Englewood Cliffs, NJ.

Ha, J., \& Jang, S. (2009). Perceived justice in service recovery and behavioral intentions: The role of relationship quality. International Journal of Hospitality Management, 28, 319-327.

Hoffman, K. D., Kelley, S. W., \& Rotasky, H.M. (1995). Tracking service failures and employee recovery efforts. Journal of Services Marketing, 9(2), 49-61.

Hoffman, K. D., \& Kelley, S. W. (2000). Perceived Justice Needs and Recovery Evaluation: A Contingency Approach. European Journal of Marketing, 34(3/4), 418-32.

Karande, K., Magnini, V. P., \& Tam, L. (2007). Recovery voice and satisfaction after service failure: an experimental investigation of mediating and moderating factors. Journal of Service Research, 10(2), 187-203.

Karatepe, O. M. (2006). Customer complaints and organizational responses: The effects of complaints' perceptions of justice on satisfaction and loyalty. International Journal of Hospitality Management, 25(1), 69-90.

Kau, A. K., \& Loh, E. W. Y. (2006). The effects of service recovery on consumer satisfaction: a comparison between complainants and non-complainants. Journal of Services Marketing, 20(2), 101-11.

Keller, K. L. (1993). Conceptualizing, measuring, and managing customer based brand equity. Journal of Marketing, 57(1), $1-22$.

Kim, H. B., \& Kim, W. G. (2005). The relationship between brand equity and firms' performance in luxury hotels and chain restaurants. Tourism Management, 26, 549-560.

Kim, T., Kim, W. G., \& Kim, H. B. (2009). The effects of perceived justice on recovery satisfaction, trust, word-of-mouth, and revisit intention in upscale hotels. Tourism Management, 30, 51-62.

Lai, F., Griffin B, M., \& Babin, B. J. (2009). How quality, value, image, and satisfaction create loyalty at a Chinese telecom. Journal of Business Research, 62, 980-986. 
Mattila, A. (2001). The effectiveness of service recovery in a multi-industry setting. Journal of Services Marketing, 15(7), 583-96.

Maxham, J. III \& Netemeyer, R. (2002). A longitudinal study of complaining customers' evaluations of multiple service failures and recovery efforts. Journal of Marketing, 66(4), 57-71.

McColl-Kennedy, J. R., \& Sparks, B. A. (2003). Application of fairness theory to service failures and service recovery. Journal of Service Research, 5, 251-67.

McCollough M. A. (2000). The effect of perceived justice and attribution regarding service failure and recovery on post-recovery customer satisfaction and service quality attributes. Journal of Hospitality \& Tourism Research, 24(4), 423-447.

McCollough, M. A., \& Bharadwaj, S. G. (1992). The recovery paradox: an examination of customer satisfaction in relation to disconfirmation, service quality, and attribution based theories. American Marketing Association, Chicago.

Nguyen, N., \& Gaston Leblanc, G. (2001). Corporate image and corporate reputation in customers' retention decisions in services. Journal of Retailing and Consumer Services, 8, 227-236.

Ok, C., Back, K., \& Shanklin, C. W. (2005). Modeling roles of service recovery strategy: a relationship-focused view. Journal of Hospitality and Tourism Research, 29(4), 484-507.

Patterson, P. G., Cowley, E., \& Prasongsukarn, K. (2006). Service failure recovery: the moderating impact of individual-level cultural value orientation on perceptions of justice. International Journal of Research in Marketing, 23(3), 263-277.

Roberts, P. W., \& Dowling, G. R. (2002). Corporate reputation and sustained superior financial performance. Strategic Management Journal, 23, 1077-93.

Sekaran, U. (2003). Research methods for business: A skill building approach. John Wiley and Sons, Inc.

Selnes F. (1993). An examination of the effect of product performance on brand reputation, satisfaction and loyalty. European Journal of Marketing, 27(9), 19-35.

Smith, A., \& Bolton, R. (1998). An experimental investigation of customer reactions to service failure and recovery encounters: paradox or peril. Journal of Services Research, 1(1), 65-81.

Smith, A. K., Bolton, R. N., \& Wagner, J. (1999). A model of customer satisfaction with service encounters involving failure and recovery. Journal of Marketing Research, 36(3), 356-373.

Sparks, B. N., \& McColl-Kennedy, J. R. (2001). Justice strategy options for increased customer satisfaction in a services recovery setting. Journal of Business Research, 54, 209-218.

Tax, S. S., Brown, S. W., \& Chandrashekaran, M. (1998). Customer evaluation of service complaint experiences: implications for relationship marketing. Journal of Marketing, 62, 60-76.

Thibaut, J., \& L. Walker. (1975). Procedural Justice: A Psychological Analysis, Hillsdale, NJ: Erlbaum.

Walster, E., Berscheid, E., \& Walster, W. (1973). New directions in equity research. Journal of Personality \& Social Psychology, 25(2), 151-76.

Wirtz, J., \& Mattila, A. S. (2004). Consumer responses to compensation, speed of recovery and apology after a service failure. International Journal of Service Industry Management, 15(2), 150-166.

Zeithaml V. A. (1998). Consumer perceptions of price, quality, and value: a means-end model and synthesis of evidence. Journal of Marketing, 52(3), 2-22.

Zemke, R. (1993). The art of service recovery: fixing broken customers and keeping them on your side. American Management Association, New York, 463-476. 
Table 1. Respondents' Profile

\begin{tabular}{|lcc|}
\hline Variable & Frequency & \% \\
\hline $\begin{array}{l}\text { Gender } \\
\text { Male }\end{array}$ & 70 & 65.4 \\
Female & 37 & 35.6 \\
\hline Age & & \\
& 1 & 0.9 \\
20 years old and below & 36 & 33.6 \\
21 to 30 years old & 55 & 51.4 \\
31 to 40 years old & 13 & 12.1 \\
41 to 50 years old & 2 & 1.9 \\
51 years old and above & & \\
Marital Status & 35 & 32.7 \\
Single & 71 & 66.4 \\
Married & 1 & 0.9 \\
Others & 1 & \\
Educational Level & 9 & 0.9 \\
High school and below & 27 & 8.4 \\
Certificate/Diploma & 60 & 25.2 \\
Bachelor's Degree & 10 & 9.1 \\
Master's Degree & & 9.3 \\
PhD/ Doctorate &
\end{tabular}

Table 2. Results of the Factor Analysis

\begin{tabular}{|l|c|c|c|}
\hline \multicolumn{1}{|c}{ Variables } & \multicolumn{3}{c|}{ Components } \\
\cline { 2 - 4 } & $\mathbf{1}$ & $\mathbf{2}$ & $\mathbf{3}$ \\
\hline Compared to what you expected, the offer that I received was fair. & .269 & $\mathbf{. 8 1 3}$ & .023 \\
Taking everything into consideration, the Iran Air's offer was quite fair. & .164 & $\mathbf{. 8 8 3}$ & -.081 \\
Given the circumstances, I feel that Iran Air has offered an adequate & .392 & $\mathbf{. 7 1 6}$ & -.288 \\
compensation. & & & \\
My complaint was handled in a very timely manner. & -.107 & .357 & $\mathbf{. 6 1 1}$ \\
My complaint was not resolved as quickly as it should have been. & -.092 & -.252 & $\mathbf{. 8 2 3}$ \\
The procedure for handling my complaint was complicated. & .194 & -.161 & $\mathbf{. 7 7 0}$ \\
Employees were courteous to me. & $\mathbf{. 8 9 2}$ & .168 & -.057 \\
Employees' communication with me was appropriate. & $\mathbf{. 9 2 6}$ & .077 & .062 \\
Employees put the proper effort into resolving my problem. & $\mathbf{. 8 0 8}$ & .161 & .091 \\
Employees showed a real interest in trying to be fair. & $\mathbf{. 6 5 6}$ & .332 & -.136 \\
Employees showed a concern. & $\mathbf{. 5 8 5}$ & .233 & -.252 \\
\hline Eigenvalue & 4.42 & 1.96 & 1.69 \\
Variance Explained (\%) - Total 72.47\% & 26.58 & 46.20 & 62.02 \\
\hline
\end{tabular}

Table 3. Reliability Statistics of the Factors

\begin{tabular}{|c|c|c|c|c|}
\hline Constructs & $\begin{array}{c}\text { No of Items } \\
\text { Remain }\end{array}$ & Items Dropped & Cronbach Alpha & N \\
\hline Distributive Justice & 3 & - & 0.856 & 107 \\
Procedural justice & 3 & - & 0.633 & 107 \\
Interactional Justice & 5 & - & 0.873 & 107 \\
Corporate image & 4 & - & 0.829 & 107 \\
Recovery Satisfaction & 4 & - & 0.834 & 107 \\
\hline
\end{tabular}


Table 4. Result of regression analysis

\begin{tabular}{|l|c|c|c|}
\hline \multirow{2}{*}{ Variable } & \multicolumn{3}{|c|}{ Standardized Beta } \\
\cline { 2 - 4 } Model variables & Step 1 & Step 2 & Step 3 \\
Distributive Justice & $0.539 * * *$ & $.249 * * *$ & .023 \\
Procedural Justice & 0.041 & -.025 & -.063 \\
International Justice & $0.367 * * *$ & $.258 * * *$ & .075 \\
Corporate image & & $.467 * * *$ & -.179 \\
\hline Moderating variables & & & \\
CI X DJ & & & $.699 * * *$ \\
CI X PJ & & & -.048 \\
CI X IJ & & $28.141 * * *$ & $10.500 * * *$ \\
& & .720 & .789 \\
$\mathrm{~F}^{2}$ value & $59.454 * * *$ & .709 & .774 \\
Adjusted R & .641 & .080 & .069 \\
$\mathrm{R}^{2}$ change & .630 & 28.141 & 10.500 \\
F change & .641 & & \\
\hline
\end{tabular}

$* p<0.05, * * p<0.01, * * * p<0.00$

\section{Distributive justice}

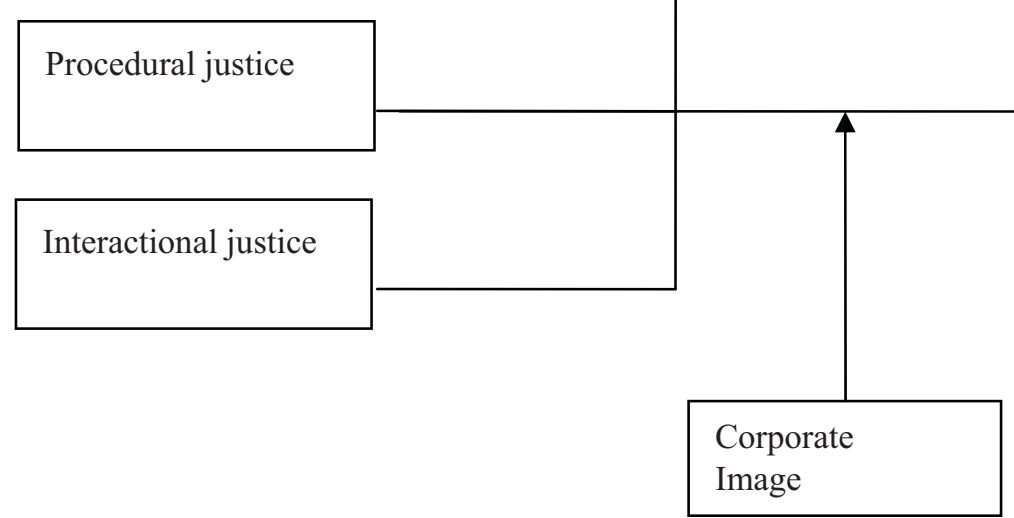

Figure 1. Research Framework 